\title{
URGENSI PENGATURAN SUI GENERIS BAGI NEGARA- NEGARA EKUATOR KHUSUSNYA INDONESIA
}

\author{
Agung Prayuda Yahya Putra \\ Magister Ilmu Hukum Padjajaran, Indonesia \\ Email: agung19007@mail.unpad.ac.id
}

\begin{abstract}
Abstrak
Kedudukan dan Pemanfaatan penggunaan GSO sampai dengan saat ini oleh negara berkembang khususnya negara-negara khatulistiwa dinilai masih menjadi masalah karena belum mencerminkan rasionalitas yang berkeadilan. Artikel ini akan membahas dua rumusann masalah yang pertama, bagaimana pengaturan sui generis bagi pemanfaatan GSO terhadap negara ekuator menurut Hukum Internasional? dan yang kedua bagaimana kedudukan Indonesia sebagai negara yang berada di jalur khatulistiwa dan urgensinya dalam pemanfaatan Geostasionary Orbit?. Tujuan penulisan artikel ini adalah mengetahui dan menganalisis pengaturan sui generis bagi pemanfaatan GSO terhadap negara ekuator menurut Hukum Internasional dan kedudukan Indonesia sebagai negara yang berada di jalur khatulistiwa dan urgensinya dalam pemanfaatan Geostasionary Orbit. Adapun metode penelitian yang digunakan adalah metode penelitian normatif. Subtansi isi rezim khusus (sui generis) usulan negara berkembang, negara khatulistiwa maupun negara lainnya intinya memiliki tuntutan yang relatif sama bahwa pengaturan penggunaan GSO menjadi wewenang UNCOPUOS dan penggunaan GSO dapat diterapkan secara adil dan memperhatikan kepentingan negara-negara khususnya negara yang memiliki karateristik alamiah yang unik dengan GSO, untuk alokasi penggunaan spektrum frekuensi dilakukan secara adil yang berdasar pada ketentuan dalam ITU. Sebagai suatu Negara yang berada di bawah garis khatulistiwa terpanjang membuat Indonesia menjadi negara yang memiliki posisi yang panjangnya sama dengan segment GSO yang terdapat di atas wilayah Indonesia. Sehingga, untuk kepentingan Indonesia kedepannya, maka pemanfaatan segment GSO yang terdapat di wilayah bangsa Indonesia harus selalu dapat terjamin guna untuk kelangsungan serta keamanan dalam memanfaatkan segmen GSO itu sendiri.
\end{abstract}

\section{Kata Kunci: Sui Generis; GSO; Negara Ekuator}

\begin{abstract}
The position and utilization of the usage of GSO by developing countries, especially equatorial countries is still considered as a problem because it does not reflect rationality fairness. This article will discuss two problems. First, how is the Sui Generis arrangement for the use of GSO for equatorial countries according to international law? and second, how is Indonesia's position as a country on the equator and its urgency in using Geostationary Orbit? The purpose of this article is to find out and analyze the Sui Generis arrangement for the usage of GSO towards the equatorial country according to international law and Indonesia's position as a country on the equator and its urgency in the Geostationary Orbit Usage. The research method used is a normative research method. The substance of the content of the special regime (sui generis) proposed by developing countries, equatorial countries and other countries essentially has relatively the same demands that the regulation of the use of GSO be the authority of UNCOPUOS and the use of GSO can be applied fairly and pay attention to the interests of countries, especially countries that have natural characteristics that unique with GSO, and the allocation of frequency spectrum use is carried out fairly based on the provisions in ITU. As a country lies at the longest equator, Indonesia is a country that has a position that is the same length as the GSO segment above the territory of Indonesia. Thus, for the benefit of Indonesia in the future, the usage of the GSO segment in the territory of the Indonesian nation must always be guaranteed in order to ensure continuity and security in utilizing the GSO segment itself.
\end{abstract}

Keywords: Sui Generis; GSO; Equatorial States 


\section{PENDAHULUAN}

\section{Latar Belakang}

Negara pada prinsipnya memikul tanggung jawab internasioal terhadap kegiatan nasional diluar angkasa dan bahwa setiap mehari bagian berhak meluncurkan atau menagadakan peluncuran sebuah objek ke luar angkasa, serta bertanggung jawab secara internasional terhadap kerusakan yang diderita dibumi, di ruang udara, maupun di luar angkasa diatur oleh dokumen internasional khusus yang memprakarsai asal usul dari terbentuknya hukum luar angkasa. ${ }^{1}$

$$
\text { Hukum ruang angkasa }
$$

internasional adalah cabang hukum internasional yang mengatur pelaksanaan kegiatan ruang angkasa. Instrumen intinya termasuk lima perjanjian internasional khusus ruang angkasa, yang diadopsi di bawah naungan Perserikatan Bangsa-Bangsa. Pertama dan yang mendasari-Perjanjian tentang Prinsip yang Mengatur Kegiatan Negara dalam Eksplorasi dan Penggunaan Ruang Angkasa, termasuk Bulan dan Badan Surgawi Lainnya (Perjanjian Luar Angkasa) menetapkan bahwa ruang luar bebas untuk eksplorasi dan penggunaan oleh semua negara

1 Marina Lits, DKK, International Space Law, BRICS LAW JOURNAL Volume IV (2017) Issue 2 , hlm. 1 bagian. Kebebasan mendasar semacam itu dilakukan oleh sejumlah aplikasi ruang angkasa yang telah menjadi bagian integral dari kehidupan manusia modern dan ekonomi global. ${ }^{2}$

Perkembangan penelitian hukum luar angkasa telah dilakukan di Uni Soviet pada penciptaan satelit buatan bumi. Peluncuran satelit pertama dilakukan oleh Uni Soviet adalah realisasi yang sesuai dengan program penelitian ilmiah tahunan Geofisika Internasional, pada 4 oktober 1957 Uni Soviet berhasil meluncurkan satelit Sputnik $I^{3}$ Konsep Mare Liberum memusatkan perhatian pada kebutuhan dunia untuk menerima doktrin terhadap kebebasan di laut, sama halnya dengan antarika. Para sarjana merumuskan apakah negara bagian memiliki hak untuk memperoleh antariksa, apakah negara bagian ekuador berhak menggunakan atau menempatkan satelit

\footnotetext{
2 Elina Morozova and Yaroslav Vasyanin, International Space Law And Satellite Telecommunications, Oxford Research Encyclopedias, 2019, Lihat, https://oxfordre.com/planetaryscience/view/10 .1093 /acrefore/9780190647926.001.0001/acref ore-9780190647926-e-75, diakses pada 6 September 2020.

3 Digital Archive International History Declassified, Pravda Newspaper Article, 'Announcement of the First Satellite', October 05, 1957, Lihat, https://digitalarchive.wilsoncenter.org/documen t/165454.pdf?v=1b97d7e06318bd134c57860e8 ba96a5d, diakses pada 6 september 2020 .
} 
di GSO tepat diatas wilayah negara tersebut. 4

GSO (geostationary orbit) merupakan sebuah orbit yang terdapat di ruang angkasa dalam ketinggian $36.000 \mathrm{~km}$ dan memiliki ketebalan sekitar $75 \mathrm{~km}$ pada khatulistiwa bumi. GSO sendiri mempunyai ciri-ciri khusus yakni terdapat keunggulan yang dapat membedakan GSO sendiri dengan bagian antariksa lainnya. Adapun keunggulan yang dimaksud yaitu periode putaran bumi hampir sama dengan periode putaran satelit ataupun benda-benda antariksa lainnya yang ditempatkan di GSO jika dilihat dari permukaan bumi. ${ }^{5}$

Fungsi satelit perlu ditempatkan di orbit tertentu dan menggunakan spektrum frekuensi radio, baik sumber daya alam terbatas. Akses ke sumber daya tidak tunduk pada apropriasi nasional dan memerlukan penggunaan rasional, efisien, dan ekonomis dalam lingkungan bebas gangguan, dikelola oleh International Telecommunication Union (ITU) - badan khusus PBB untuk informasi dan teknologi komunikasi.

4 Michael P. Scharf, Outer Space Law, Lihat, https://www.cambridge.org/core/books/customa ry-international-law-in-times-of-fundamentalchange/outer-space-

law/F365CE6892176D25FF589AC4619FD206, diakses 6 September 2020.

5 Boer Mauna, Hukum Internasional (Pengertian Peranan dan Fungsi dalam Era Dinamika Global, Bandung: Alumni, 2005, hal 447-448
Dokumen peraturan inti ITU adalah Konstitusi, Konvensi, dan Peraturan Radio, yang secara kolektif membentuk kelompok peraturan hukum internasional lain yang relevan dengan telekomunikasi satelit. 6

Keikutsertaan PBB terkait aspek hukum antariksa pada tahun 1958, setelah satelit buatan pertama Sputnik diluncurkan, United Nation General Assembly (UNGA) mengeluarkan keputusan dalam Resolusi 1348 untuk membentuk Komite Penggunaan Damai Luar Angkasa (COPUOS), pada tahun 1959 Majelis Umum membuat Komite Penggunaan Damai Luar Angkasa menjadi badan permanen dan menegaskan kembali mandatnya pada Resolusi 1472. Sidang Umum pada tahun 1962 menegaskan bahwa Perserikatan Bangsa-Bangsa akan mengkoordinasikan kerja sama internasional dalam eksplorasi dan pemanfaatan ruang angkasa secara pasifik yang dimana hal tersebut ditegaskan dalam Resolusi 1721.7

Terdapat instrument perjanjian internasional terkait pengaturan hukum ruang angkasa pada tahun 1966, SubIbid

6 Elina Morozova and Yaroslav Vasyanin, 7 Lihat, https://onuvienne.delegfrance.org/The-Committee-in-thePeaceful-Uses-of-Outer-Space-COPUOS, diakses 7 September 2020 
komite mempertimbangkan adanya sebuah perjanjian pada Sidang Umum dan dituangkan dalam Resolusi 2222. Perjanjian ini didasarkan pada PrinsipPrinsip Hukum yang mengatur mengenai kegiatan Negara-negara dalam Eksplorasi dan penggunaan Luar Angkasa yang diadopsi oleh Sidang Umum Resolusi 1962 pada tahun 1963, namun terdapat beberapa tambahan ketentuan baru. Perjanjian tersebut ditandatangani pada bulan Januari 1967 oleh tiga negara, yakni: Inggris, Amerika dan Federasi Rusia, dan berlaku pada bulan Oktober 1967 yang disebut Outer Space Treaty yang ditelah diratifikasi 103 negara. ${ }^{8}$ Perjanjian ini memberikan kerangka dasar mengenai hukum ruang angkasa yang dimana juga terdapat Prinsip-Prinsip dalam Perjanjian tersebut, Adapun Prinsip-Prinsip tersebut yakni: ${ }^{9}$

1. Dalam melakukan Eksplorasi dan Pemanfaatan ruang angkasa harus dilakukan untuk sebuah kepentingan dan kepentingan negara serta seluruh umat manusia.

8 United Nations Office For Outer Space Affairs, Treaty on Principles Governing the Activities of States in the Exploration and Use of Outer Space, including the Moon and Other Celestial Bodies, Lihat,https://www.unoosa.org/oosa/en/ourwor $\mathrm{k} / \mathrm{spacelaw} /$ treaties/introouterspacetreaty.hml, diakses pada 8 September 2020

$$
{ }^{9} \text { Ibid }
$$

2. Semua Negara bebas melakukan Eksplorasi dalam penggunaan Luar Angkasa.

3. Negara tidak boleh menempatkan senjata nuklir atau senjata pemusnah massal lainnya di orbit atau di benda langit atau menempatkannya di luar angkasa.

4. Negara bertanggung jawab dalam kerusakan yang disebabkan oleh objek antariksa Negara tersebut.

5. Negara harus menghindari kontaminasi dari ruang angkasa dan benda langit yang dapat membahayakan.

GSO sendiri tidak hanya memiliki keunggulan di ruang angkasa namun juga ada berbagai macam persoalan yang terikat Dikarenakan pergerakan GSO yang mengelilingi bumi. 10 GSO (Geos Stationary Orbit) yang letaknya berdampingan dengan bidang khatulistiwa bumi jika dilihat dari permukaan wilayah khatulistiwa bumi membuat GSO itu sendiri menjadi tempat untuk ditempatkannya satelit oleh negara ataupun non-negara. ${ }^{11}$ Oleh sebab itu terdapat beberapa pertentangan mengenai peletakan satelit oleh negara maupun non-negara di GSO, sehingga hal ini menjadi pembahasan dalam pertemuan Declaration of $1^{\text {st }}$ Meeting of

10 Michael J. Finch, Limited Space: Allocating the Geostationary Orbit, Northwestern Journal of International Law and Business: Vol.7, Issue 4, 1986, hal 789

11 H.L. Van Traa-Engelman, Commercial Utilization of Outer Space, Leiden: Martinus Nijhoff Publishers, 1993, hal 89 
Equatorial Countries yang biasa juga disebut Bogota Declaration. Pertemuan tersebut membahas mengenai pembagian wilayah dalam menempatkan satelit di GSO yang dimulai pada tahun 1976.12

Perserikatan Bangsa-Bangsa melalui badan Committe on the Peaceful Uses of Outer Space (COPUOUS) selalu melakukan upaya untuk merumuskan ketentuan-ketentuan internasional atas pemanfaatan GSO mengingat GSO sendiri juga bermanfaat untuk seluruh masyarakat internasional. Pembahasan pertama kali GSO terjadi pada tahun 1974 di Amsterdam dalam pertemuan International institut of Space Law, International Astronoutical Federation (IAF) yang kemudian dilanjutkan pada pertemuan Negara-negara khatulistiwa sehingga pada tahun 1976 menghasilkan Deklarasi Bogota, yang dimana beberapa Negara-negara khatulistiwa salah satunya Indonesia menandatangani Deklarasi tersebut yang isinya memuat tuntutan mengenai kedaulatan atas jalur GSO yang berada tepat di atas Negaranegara khatulistiwa. Deklarasi Bogota sendiri akan dikembangkan pada tahun 1982 di Quito, Equador akan tetapi tidak mengeluarkan Deklarasi yang baru,

12 E.M. Scoop, Handbook of Geostationary Orbits, USA: Microcosm Inc., Kluwer Academic Publishers, 1994, hal10 dikarenakan banyaknya pandangan yang berbeda mengenai strategi yang akan ditempuh.

$$
\text { GSO sendiri memiliki }
$$
keterbatasan letak wilayah yang dimana wilayah dari GSO hanya ada pada garis khatulistiwa saja sehingga hal tersebut menjadi sumber perselisihan oleh Negara-negara yang merasa bahwa Negara-negara tersebut dirugikan akan praktik penempatan satelit di GSO, yang dimana terdapat 402 satelit yang berada di GSO dan terus mengalami peningkatan setiap tahunnya. ${ }^{13}$ Satelit-satelit tersebut kebanyakan milik Negara-negara maju sehingga terdapat ketidakadilan ketika melakukan pemanfaatan sumber daya tersebut.

International Telecommunication Union (ITU) merupakan sebuah lembaga khusus yang berada dalam naungan Perserikatan Bangsa-Bangsa bertujuan untuk menentukan pembagian penempatan satelit di GSO dan juga memberikan fasilitas koordinasi satelit serta juga menangani masalah-masalah yang berkaitan dengan teknologi dan komunikasi.

International Telecommunication Union (ITU) didirikan

13 List of Satellites in Geostationary Orbit. http://www.satsig.net/sslist.htm, diakses pada tanggal 10 September 2020. 
pada tanggal 17 Mei tahun 1985,14 International Telecommunication Union (ITU) sendiri menggunakan International Tellocommunication Union Allocation Mechanism dalam menangani masalah masalah yang berkaitan dengan pembagian wilayah penempatan satelit di GSO.15 Walaupun ITU telah mengabsahkan beragam mekanisme yang diperuntukkan dalam penempatan satelit sesuai dengan kinerja lembaga tersebut, akan tetapi komersialisasi pada praktiknya yang telah berkembang menjadikan tantangan tersendiri untuk perspektif hukum dari GSO.

Sebagai salah satu Negara yang berada di bawah garis khatulistiwa membuat Indonesia juga memiliki jalur geostasioner, oleh karenanya Indonesia bersama Negara-negara yang berada di bawah garis khatulistiwa lainnya yakni Colombia, Equador, Brazil, Kenya, Congo, Zaire, dan Uganda ingin memanfaatkan hal tersebut guna untuk kepentingan nasional yang beragam terlebih lagi jalur geostasioner tersebut sangat berguna untuk pemantauan cuaca dan lingkungan serta juga untuk telekomunikasi. Karena keuntungan-keuntungan yang diberikan

14 Lotta Viikari, The Environmental Element in Space Law, Assessing the Present and Charting the Future, Leiden: Martinus Nijhoff Publishers, 2007, hal 85

15 Ibid, hal 86 oleh orbit geostastioner tersebut sehingga dibuatkanlah satu rezim hukum yang khusus yakni Sui Generis tentang orbit geostasioner. Rezim khusus ini mempunyai tujuan utama yakni memberikan perlindungan terhadap Negara-negara yang berada di bawah garis khatulistiwa namun juga harus melihat prinsip-prinsip kerja sama atas Negara-negara lain ketika melakukan pemanfaatan terhadap sumber-sumber yang berada di antariksa. ${ }^{16}$

Aspek hukum penggunaan Geostasionary Orbit (GSO) banyak dibicarakan dalam persidangan Komite Penggunaan Secara Damai Ruang Angkasa. Persoalan utama yang dibicarakan dalam sidang tersebut ialah membuat Rezim hukum khusus mengenai GSO. Namun, terdapat beberapa perbedaan pandangan antara suatu Negara dan kelompok Negara terhadap status hukum dari GSO itu sendiri. Ada yang berpandangan bahwa GSO itu sendiri termasuk dalam bagian dari ruang angkasa dan telah diatur di dalam Perjanjian Ruang Angkasa 1976, serta ada juga yang berpandangan harus diadakannya suatu Rezim hukum yang khusus untuk GSO dikarenakan GSO itu sendiri memiliki letak dan karakteristik khusus.

${ }^{16}$ Boer Mauna, Op.Cit, hal 448 
Karena memulai tantangan dari Negara-negara barat, pada tahun 1982 Negara-negara khatulistiwa merubah tuntutannya dari tuntutan kedaulatan menjadi hak pelestarian (right of preservation). Namun, hal tersebut tidak dapat dipertahankan sehingga pada tahun 1993 negara-negara yang berada di bawah garis khatulistiwa lebih memberikan penekanan terhadap penggunaan GSO yang harus adil dan merata untuk semua Negara dan tidak lagi menekankan pada tuntutan kedaulatan. ${ }^{17}$

Sampai saat ini penggunaan dan pemanfaatan GSO dari negara-negara berkembang dilihat belum menggambarkan rasionalitas yang adil dan merata terhadap negara-negara anggota PBB/ITU. Negara berkembang dan utamanya negara-negara khatulistiwa terus berjuang menuntut adanya rasionalitas dan keadilan, sehingga kepentingan negara-negara berkembang serta negara-negara khatulistiwa dapat juga memanfaatkan dan menggunakan GSO tersebut untuk dapat menempatkan satelit komunikasi guna mendukung kepentingan nasional negaranya.

Status hukum komersialisasi GSO sampai saat ini masih menjadi suatu 17 Ibid perdebatan. Perbedaan tersebut timbul dikarenakan perbedaan prinsip oleh Negara-negara khatulistiwa dan Negara maju, negara-negara khatulistiwa memiliki prinisip yang lebih menekan pentingnya pembagian yang dilakukan secara adil pada penempatan satelit di GSO, berbeda halnya dengan negara maju yang telah lebih dulu meluncurkan satelit dengan jumlah yang banyak ke GSO, Negara maju tersebut juga memiliki prinsip bahwa GSO itu sendiri sudah termasuk di dalam Space Treaty 1967 dilihat dari letak GSO yang berada di ruang angkasa. Oleh karena hal tersebut timbullah ketidakrelevanan terhadap klaim kedaulatan dan kepemilikan negara.

Perjuangan yang terus diupayakan oleh negara-negara khatulistiwa termasuk juga negaranegara berkembang adalah agar dapat ditetapkannya "suatu rezim hukum khusus" (Sui Generis Regime) terhadap GSO yang merupakan spesialisasi/kekhususan dari rezim hukum internasional yang telah ada atau telah mengatur sebelumnya. Negaranegara berkembang dituntut harus mampu mengeksplor apa yang akan menjadi isi subtansi dalam rezim hukum tersebut, dan hal ini menjadi hal menarik untuk diketahui tantangan dalam 
mewujudkannya. Penelitian ini bertujuan untuk menganalisis pengaturan sui generis GSO bagi negara-negara Ekuator dan dan urgensianya terhadap indonesia yang termasuk sebagai negara khatulistiwa dalam memperjuangkan untuk adanya pengaturan internasional rezim hukum khusus atas GSO.

\section{Rumusan Masalah}

1. Bagaimana pengaturan sui generis bagi pemanfaatan GSO terhadap negara ekuator menurut Hukum Internasional?

2. Bagaimana kedudukan Indonesia sebagai negara yang berada di jalur khatulistiwa dan urgensinya dalam pemanfaatan Geostasionary Orbit?

\section{Metode Penelitian}

Jenis penelitian yang digunakan oleh peneliti dalam menyusun Penelitian ini adalah jenis penelitian normatif. Adapun pendekatan yang digunakan dalam penelitian ini adalah, antara lain; Pendekatan perundang-undangan (Statue Approach), pendekatan kasus (case approach) dan pendekatan perbandingan (comparative approach). Analisis yang digunakan dalam penelitian ini adalah analisis data deskriptif dengan menggunakan pendekatan kualitatif terhadap data primer dan data sekunder.
PEMBAHASAN

Pengaturan Sui Generis bagi

Pemanfaatan GSO Terhadap Negara

Ekuator Menurut Hukum

\section{Internasional}

\section{A. Pemanfaatan GSO Menurut Hukum Internasional}

Seperti halnya laut lepas, hukum ruang angkasa juga tunduk terhadap rezim internasional yang berdasar dalam pelaksanaan dua prinsip, yaitu prinsip kebebasan penggunaan dan prinsip tidak dapat dimiliki yaitu:18

1. Non-Appropiation Principle (prinsip tidak dapat dimiliki)

2. Freedom Exploitation Principle (prinsip kebebasan penggunaan) Geostasionary Orbit (GSO) memiliki suatu keistimewaan, pada saat sebuah satelit ditempatkan di GSO maka satelit tersebut akan mengelilingi bumi dengan perputaran bumi itu sendiri. Hal tersebut dikarenakan perputaran dari GSO itu sendiri yang mengelilingi bumi sesuai dengan perputaran bumi. ${ }^{19}$ Dalam pengaturannya, status GSO sendiri merupakan sumber daya alam yang

18 Nurul Sri Fatmawati, Analisis Implementasi Pedoman PBB tentang Mitigasi Sampah Antariksa (Analysis on Implementation of UN Space Debris Mitigation Guidelines), Jurnal Analisis dan Informasi Kedirgantaraan Vol. 9 No. 2 Desember 2012, hal. 2

${ }^{19}$ Bour Mauna, Op.Cit, hal 449 
terbatas hal tersebut diatur dalam pasal

33 (2) ITU 1973 sebagai berikut

"Dalam menggunakan
frekuensi radio di luar
angkasa harus mengingat
bahwarana
keterbatasan frekuensi
dalam Orbit Satelit
Geostasioner
sehingganya penggunaan
frekuensi tersebut harus
digunakan secara efisien
dan ekonomis".

Negara-negara khatulistiwa

merasa semakin dirugikan dengan dikembangkannya prinsip First Come First Served oleh Space Faring States dimana dalam hal itu terdapat Hak Berdaulat di dalam GSO, hal tersebut membuat suasana kompetisi yang mengakibatkan timbulnya Technological Appropriation. Sehingga Negara-negara khatulistiwa merasa bahwa perlu adanya pengaturan Hukum Internasional agar tidak merugikan pihak mereka guna untuk pemanfaatan sumber daya dari GSO tersebut. ${ }^{20}$

Indonesia yang dalam hal ini merupakan negara khatulistiwa menuntut kedaulatan untuk pemanfaatan GSO yang berdasar pada national statement, tuntutan tersebut juga disertai dengan kompromi yakni :21

20 Sefriani, Hukum Internasional: Suatu pengantar, Rajawali Pers,Yogyakarta, 2009, hal 229

21 Arifin, Seru, Hukum Perbatasan Darat Antar Negara, Sinar Grafika, Jakarta, 2014, hal. 86 a) Adanya pengakuan atas GSO sebagai sumber daya alam terbatas serta mempunyai spesifikasi yang khusus

b) Adanya hak berdaulat (Souvereign Right) yang dimiliki oleh negaranegara khatulistiwa terhadap GSO di atas wilayahnya

c) Hak berdaulata yang dimaksudkan tujuannya hanya untuk kepentingan rakyat negaranegara khatulistiwa

d) Pada prinsipnya memberikan kebebasan terhadap satelit-satelit yang digunakan untuk kemanusiaan dan perdamaian Pengaturan pemanfaatan dan penggunaan GSO sesuai dengan wujud bendanya dan sifat manfaat teknis dalam pemanfaatan dan penggunaannya "terwadahi" dalam dua rumpun hukum internasional yaitu rumpun hukum internasional dalam sistem United Nation Committe on The Pacefull Uses of Outer Space (UNCOPUOS) serta rumpun hukum internasional dalam sistem /International Tellecomunication Union/ITU. Pengaturan GSO dalam dua sistem Organisasi dalam Koordinasi Perserikatan Bangsa-Bangsa dimaksud dapat dilihat secara ringkas sebagai berikut: 


\section{Pengaturan GSO dilihat dari Space Treaty 1967}

Pengaturan terhadap GSO sebagai wujud bendanya tidak diatur secara eksplisit dalam Space Treaty 1967. Akibat letak dari GSO yang wilayahnya berada di antariksa, sehingga aturan yang berlaku yaitu ketentuanketentuan yang ada dalam Space Treaty 1967, hal ini dapat diindikasikan dari melihat ketentuan artikel 1 sebagai berikut:

"Luar angkasa, termasuk bulan dan benda langit lainnya, akan bebas untuk dieksplorasi dan digunakan oleh semu Negara, tanpa diskriminasi dalam bentuk apapun, atas dasar persamaan dan sesuai dengan Hukum Internasional". ${ }^{22}$

Berdasarkan hal itu maka setiap negara sesuai dengan ketentuan dalam treaty dapat memanfaatkannya secara adil tanpa diskriminasi antara negara satu dengan negara lain. Selanjutnya ketentuan dari Artikel 2 yang menyatakan:
"Luar angkasa termasuk bulan dan benda-benda khusus lainnya tidak tunduk pada perampasan nasional dengan klaim kedaulatan, atau dengan cara lain." ${ }^{23}$

Aturan ini menegaskan

bahwa antariksa adalah wilayah bersama kepentingan umat manusia yang tidak boleh dimiliki dan dikuasai dengan cara apapun oleh suatu negara. Pemanfaatan dan penggunaan antariksa dapat dilakukan oleh setiap negara dengan tujuan damai. Kentuan ini sebagiamana dinyatakan dalam arikel 4:

"Bulan dan benda-benda langit lainnya dapat dimanfaatkan oleh semua Negara pihak dalam perjanjian ini secara ekslusif dengan tujuan damai ".

Ketentuan pengaturan dalam Space Treaty 1967 terhadap GSO sebagai upaya perluasan makna pengertian "benda langit lainnya and Part of Outer space" adalah kehendak negara-negara yang mengacu dan mendasarkan bahwa GSO adalah juga sebagai suatu benda langit yang berupa jalur Orbit adalah wilayah strategis bagi penempatan wahana antariksa 
dan sebagai sumber daya alam memliki sifat yang terbatas, dan oleh karenanya penggunaan dan pemanfaatannya perlu diakomodir dalam ketentuan internasional, dalam hal ini Space Treaty 1967, dalam hal ini sifatnya sangat normatif. karena sebagai perluasan penafsiran pada pengertian dan makna yang terkandung dari kata "celestial bodies-and Part of Outer space" dan belum diakui sebagai hukum internasional positif dan mengikat. ${ }^{24}$

Karena letak dan sifatnya yang hampa akan udara, sehingga diberlakukannya rezim hukum ruang angkasa terhadap GSO. Hal tersebut membuat berlakunya dua prinsip dalam penggunaan GSO yakni Prinsip Commn Heritage of Mankind dan juga Prinsip Res Nullius. Negara maju dalam hal ini lebih menguasai penggunaan atas GSO hal tersebut dikarenakan kemampuan teknologi dari

24 Muhammad Megah, Kajian Aspek Hukum Internasional Mengenai Kegiatan Wisata Antariksa [Study of International Legal Aspects Regarding of Space Tourism Activities], Jurnal Analisis dan Informasi Kedirgantaraan Vol. 9 No. 2 Desember 2012, hal. 4 negara maju lebih unggul daripada negara-negara berkembang termasuk juga negara khatulistiwa yang membuat adanya ketidak seimbangan antara negara peserta dalam penggunaan dan pemanfaatan GSO.

\section{GSO dalam International} Telecommunication Union (ITU) Convention

Pengaturan GSO dilihat dari aspek sifat manfaat teknis sebagai sumber daya alam terbatas , diatur dalam artikel 33 ayat (2) dalam ITU Convention tahun 1973 yakni:

"Dalam penggunaan pita frekuensi untuk sumber layanan radio, perlu diketahui bahwa frekuensi radio dan Orbit Satelit Geostasioner merupakan sumber daya alam yang terbatas, sehingga harus digunakan secara efisien dan ekonomis".

Hal ini justru

menimbulkan

ketidakseimbangan antara negara berkembang dan negara maju yang dikarenakan pemanfaatan GSO hanya tergantung kepada kebutuhan negara, sehingga sangat jelas hanya negara majulah yang bisa 
memanfaatkan GSO karena mempunyai teknologi yang lebih unggul berbeda halnya dengan negara berkembang.

Pada Sidang International Telecommunication Union (ITU) tahun 1977 di Jenewa, yang menghasilkan Deklarasi Bogota 1976 (sebagai wujud perjuangan negara-negara termasuk didalamnya negara khatulistiwa yang diperjuangkan dalam forum UNCOPUOS disuarakan dalam sidang ini. Namun dalam sidang ini negara-negara khatulistiwa gagal memperjuangkan memasukan agenda pembahasannya dalam sidang ITU. Hasil dari sidang tesebut menetapkan bahwa UNCOPUOS lah yang dianggap tepat untuk membahasnya. Selanjutnya pada pertemuan Naerobi (Kenya) 1982,25 tuntutan negara-negara khatulistiwa dan hasil UNISPACE 1982 sebagai hasil pembahasan dalam UNCOPUOS telah dapat mempengaruhi rumusan

25 SILWANUS ULI SIMAMORA, Tanggungjawab Negara Peluncur Benda Angkasa Terkait Masalah Sampah Luar Angkasa (Space Debris) Berdasarkan Liability Convention 1972, JOM Fakultas Hukum Volume III Nomor 2, Oktober 2016, hal. 4 pemutakhiran ketentuan ITU, indikasi pengaruh tersebut dalam hal ini dapat terlihat dalam perubahan ketentuan artikel 33 ayat (2) yang bunyinya menjadi sebagai berikut:

"Semua Negara memiliki akses yang sama untuk layanan komunikasi radio antariksa dalam penggunaan GSO, artikel tersebut sebelumnya berbunyi: dalam penggunaan pita frekuensi untuk sumber layanan radio, perlu diketahui bahwa frekuensi radio dan Orbit Satelit Geostasioner merupakan sumber daya alam yang terbatas, sehingga harus digunakan secara efisien dan ekonomis".

Semua negara oleh ITU, mendapatkan kesempatan akses secara adil atas pemanfaatan frekuensi radio dan GSO. Perkembangan selanjutnya pada pertemuan WARC tahun 1985, agar setiap negara mendapatkan kesempatan yang sama untuk pemanfaatan GSO tanpa harus melihat tingkat perkembangan kemampuan ekonomi ataupun ilmu pengetahuan maka diajukan dan dibahaslah dalam sidang ini suatu prinsip penggunaan GSO yaitu: Prinsip apriori planning. 
Dalam

perkembangan

pembahasan dan penetapan

rencana apriori planning ini ternyata memberikan dampak yang luas, terlebih pada tuntutan yang sering diajukan oleh Negara khatulistiwa yang menegaskan bahwa dengan prinsip apriori planning ini negara khatulistiwa sebagai negara yang secara geografis dan secara alamiah punya keistimewaan. prinsip ini dinilai akan dapat merugikan kedudukan dan kepentingannya sebagai negara-negara yang memiliki keistimewaan khusus terhadap GSO dibanding dengan negara- negara lain diluar khatulistiwa. Pada perkembangan lanjutnnya terdapat beberapa ketentuan penting yang mengatur mengenai persoalan GSO yang tertuang di dalam Konstitusi ITU 1994 dan juga pada Radio Regulation. ${ }^{26}$

Dalam Artikel 19 ayat (11 butir a) dan Artikel 44 Konstitusi ITU mengatakan bahwa: spektrum frekuensi radio serta GSO merupakan sumber daya alam yang terbatas sehingga harus digunakan secara efisien, rasional dan ekonomis, agar negara ataupun kelompok negara memiliki persamaan akses terhadap sumber daya alam tersebut, namun harus mempertimbangkan kebutuhan khusus negara berkembang serta situasi geografis negara-negara tertentu.

Pengaturan tersebut dimaksudkan agar dapat mengakomodasikan kepentingan negara-negara yang memiliki jangkauan jauh kedepan. Tetapi pada kenyataannya dengan adanya ketentuan tersebut malah justru menimbulkan masalahmasalah yang baru berupa pengajuan "Papers Satellites" oleh beberapa Negara, Papers Satellites yang dimaksud ialah pengajuan slot-slot orbit tertentu atas satelit-satelit yang rencana dan waktu peluncurannya belum jelas. Dengan adanya Papers Satellites yang diajukan oleh negara-negara justru akan dapat mengurangi keoptimalan dalam pemanfaatan 
GSO dan bisa menutup peluang negara-negara lain. ${ }^{27}$

2. United Nations Conference on the Explore Space (UNISPACE) tahun $1982 \mathrm{di}$ Wina

Deklarasi tentang GSO yang berbunyi:

a) Increasing members of satellite are being use of various porpuses by different contries.

b) Desirable that member states, within the ITU:

I. Continue to evolve some criteria for the most equitable and efficient usesage of GSO and the $R F$ spectrum;

II. To develop planning methods/

arrangements that are based on the genuine needs both present and future;

III. Such a planning method should take into account the specific needs of the developing countries as well as the special geographical situation

of particular countries.

Sesuai dengan apa yang termaktub di dalam Space treaty yang memberikan pandangan bahwasanya GSO ialah bagian dari hukum ruang angkasa yang pemanfaatan sumber daya alamnya terbatas dan harus digunakan secara efisien, rasional, adil dan ekonomis, sekarang telah sampai pada titik jenuh yang berbahaya. Pembahasan GSO dalam forum UNCOPOUS dari tahun 1978 sampai dengan tahun 2015 yang pembahasannya khusus ditujukan agar membahas GSO dari sisi politik dan hukum ruang angkasa, sampai saat ini masih terdapat perbedaanperbedaan pandangan oleh negara-negara berkembang dan negara maju. Perbedaan yang dimaksud ialah negara berkembang berkeinginan agar diadakannya satu rezim khusus yang mengatur persoalan mengenai GSO, namun tidak demikian halnya oleh negara maju. ${ }^{28}$ 


\section{B. Rezim Hukum Khusus oleh Negara-Negara}

Tuntutan adanya pengaturan khusus terhadap GSO hingga kini masih terus diperjuangkan oleh negara khatulistiwa termasuk didalamnya negara berkembang. GSO tidak secara jelas diatur dalam Space Treaty 1967 karena ketentuannya yang bersifat umum dan belum dapat diterapkan terhadap situasi dan sifat unik yang dimiliki GSO dan aturan-aturan dalam ITU semata. Permasalahannya terletak pada subtansi isi Sui Generis Regim atas GSO, yakni: apakah GSO bebas digunakan atau berada dibawah kedaulatan negara khatulistiwa, ataupun diberlakukan hak preferensi terhadap Negara tertentu, atau bahkan aspek hukum lainnya.

\section{Deklarasi Bogota 1976}

$$
\begin{aligned}
& \text { Deklarasi Bogota } \\
& \text { ditandatangani oleh perwakilan } \\
& \text { dari negara-negara khatulistiwa } \\
& \text { yakni: Brasil, Ekuador, Kongo, } \\
& \text { Kolombia, Kenya, Indonesia serta } \\
& \text { Zaere pada Tahun } 1976 \text { di Bogota, } \\
& \text { dan oleh karenanya dikenal } \\
& \text { dengan Deklarasi Bogota Tahun } \\
& \text { 1976. Deklarasi ini pada dasarnya } \\
& \text { merupakan tuntutan dari negara- } \\
& \text { negara khatulistiwa yang berisi }
\end{aligned}
$$

Dan Tantangan Pengembangannya, Jurnal Hukum dan Pembangunan Januari - Maret 2001, hal. 5 penuntutan kedaulatan terhadap

jalur Orbit GSO yang letaknya berada diatas Negara-negara khatulistiwa/tepat berada diatas wilayah kedaulatan mereka. ${ }^{29}$ Pengertian GSO dalam Deklarasi Bogota 1976 ini adalah sebagai berikut:

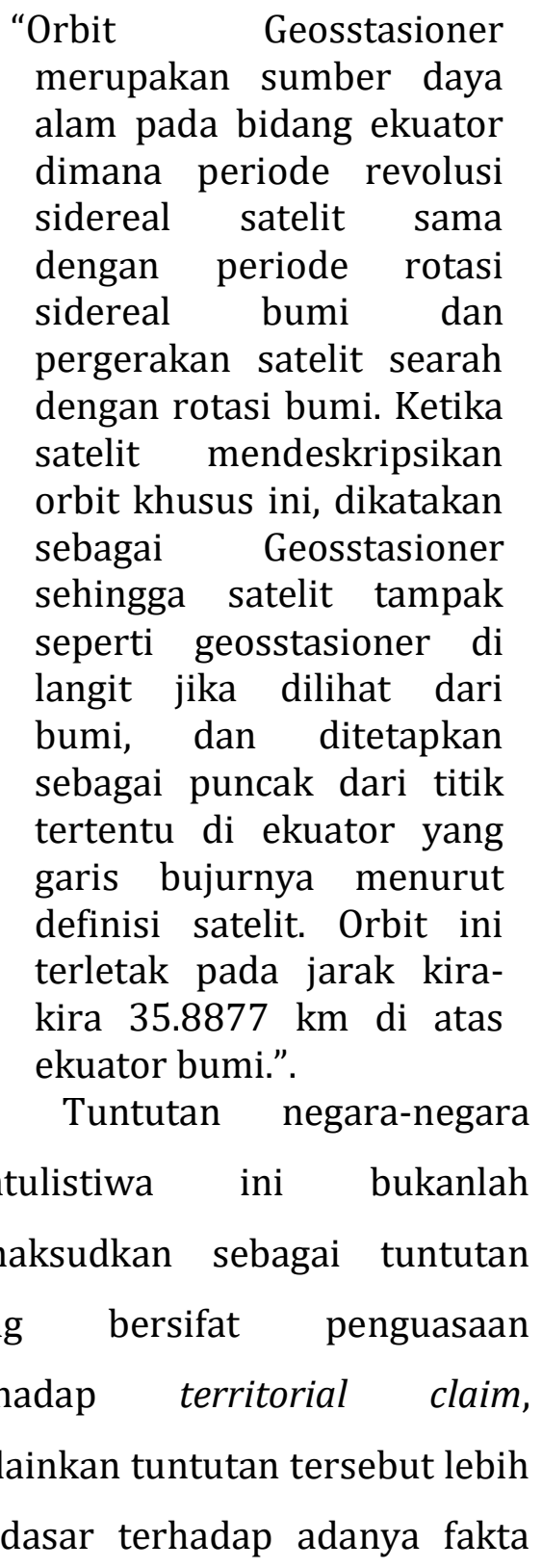

${ }^{29}$ Juajir Sumardi, Hukum Ruang Angkasa (Suatu Pengantar), Jakarta, Pradnya Paramita, 1996, hal 40 
yang dipandang mereka sebagai ketidakadilan yang telah berlangsung dalam penggunaan GSO yang didasari prinsip kebebasan yang bermanfaat untuk semua Negara yakni prinsip First Come First Served. Dampak dari penerapan prinsip ini berupa pemanfaatan GSO yang didominasi oleh Negara-negara maju sebab mereka mempunyai kemampuan atas itu baik dari aspek teknologi maupun finansial. ${ }^{30}$

Poin-poin penting yang ditegaskan sebagai isi dalam Deklarasi ini adalah bahwa adanya kepentingan yang nyata (national interest) dari negara berada diatas wilayah sovereignty/kedaulatan negara mereka. Selanjutnya, GSO is a part of outer space which has a limited natural resource (GSO merupakan bagian dari antariksa sebagai sumber daya alam terbatas), dan memiliki interdependensi yang tinggi (higly Interdependence) dalam berbagai aspek dalam kepentingan pemanfaatannya. Perkembangan perjuangan

30 Bandingkan, Kaczorowska, A, Public International Law. fourth edition. Routledge. London and New York, 2010, hal 26 negara-negara khatulistiwa termasuk didalamnya Indonesia terhadap GSO yang dimulai dari deklarasi Bogota mendapatkan hal yang positif, sehingga pada sidang sub komite hukum tahun 1984 berhasil mengajukan Working Paper untuk dibahas (Doc No.A/AC.105/C.2/L.147) yang berisikan prinsip yang diusulkan untuk dipatuhi negara dalam pemanfaatan GSO.

Prinsip-prinsip yang merupakan subtansi ketentuan rezim khusus terhadap GSO ini yaitu sebagai berikut:

1. Exclusively for peaceful purposes and the benefit of mind kind;

2. Sui generis regime and rights of equatorial countries;

3. Oppotune and appropriate utilization;

4. Preferential rights;

5. Prior authorization;

6. International Co-operating and efficient;

7. Transfer of technology;

8. Removal of non-opertional or unutilized space object from the orbit.

\section{Usulan negara-negara}

Kelompok 77 
Pada konverensi tersebut secara spesifik membahas masalah terkait penggunaan GSO dalam hal ini berkaitan dengan kebutuhan serta adanya kemungkinan untuk mengoptimumkan penggunaanya, yang berguna untuk menetapkan tindakan-tindakan yang akan dilakukan agar mencapai tujuan yang dimaksud. Pada kesempatan tersebut negara-negara khatulistiwa kembali memberikan usulan untuk membentuk suatu rezim hukum khusus terhadap GSO dengan mengedepankan suatu kepentingan yang mendasar bagi negara-negara khatulistiwa yang merasa memiliki situasi geografis yang spesial. Dalam sidang ini negara-negara yang tergabung dalam kelompok 77, sukses dalam memperjuangkan deklarasi mengenai GSO yang menegaskan:

a. Increasing members of satellite are being use of various porpuses by different countries.

b. Desirable that member states, whitin the ITU:

(1) Continue to evolve some criteria for the mosteqitable and efficient useage of GSO and the Radio frequency Spectrum.

(2) To develop planning methods/ arrangements that are based on the genuine needs both present and future.

(3) Such a planning method should take into account the spesific needs of the developing countries as wellas the spesicial geographical situation of particular countries

\section{Aspek Subtansi hukum (Legal Subtance)}

Bentuk/wujud hukum Sui Generis Regime terhadap penggunaan GSO belum pernah ada satupun negara yang mengusulkan, artinya dari sekian lama pembahasan GSO yang berlangsung di sidangsidang UNCOPUOS belum pernah dibahas. Apabila ada usulan yang disampaikan oleh negara, dapat dipastikan akan terjadi perdebatan dan waktu yang lama pada pembahasannya. Adapun usulan rumusan perspektif subtansi isi rezim hukum khusus yang 
disampaikan

negara-negara

(negara berkembang, negara kelompok 77, negara khatulistiwa) dikaitkan dengan kepentingan dan posisi negara maju akan sulit mendapatkan persetujuan, karena negara maju memiliki pandangan dan sikap bahwa masalah penggunaan GSO, yang memiliki kompetensi dan kewenangan secara internasional adalah ITU. ${ }^{31}$

Secara faktual, belum pernah ada usulan tentang bentuk/wujud hukum yang dimaksudkan sebagai wadah dari rezim hukum khusus penggunaan GSO dan fakta masih tegasnya perbedaan pandangan oleh negara berkembang dan negara maju terhadap posisi dan penggunaan GSO dan negara maju berpandangan bahwa hanya ITU yang memliki kewenangan unutuk hal tersebut, dari pendekatan subtansi hukum, fakta ini akan menjadi tantangan yang relatif sulit dan berat untuk

31 Hikmahanto Juwana, Hukum Internasional Sebagai Instrumen Politik: Beberapa Pengalaman Indonesia Sebagai Studi Kasus, ARENA HUKUM Volume 6, Nomor 2, Agustus 2012, hal 7 dapat memperjuangkan lebih jauh untuk adanya rezim hukum khusus terhadap penggunaan GSO dan terbentuk atau terlahir dalam koridor kewenangan UNCOPUOS.

\section{Kedudukan Indonesia sebagai negara khatulistiwa dan urgensinya dalam pemanfaatan GSO}

Seiring perkembangan Hukum Ruang Angkasa (Space Law) saat ini, yang berkaitan dengan banyaknya usaha yang dilakukan oleh negara-negara atau pihak-pihak guna untuk pemanfaatan GSO membuat timbulnnya kesadaran untuk membuat suatu aturan hukum yang tegas yang berlaku secara universal terhadap objek-objek ruang angkasa yang akan diluncurkan. Hal tersebut juga berkaitan dengan persoalan kedaulatan negara-negara yang ruang udara wilayahnya dilintasi objek ruang angkasa, disaat perjalanan menuju orbit ataupun saat akan dikembalikan ke bumi.

Pada tahun 1967 di Bogota (Colombia) negara-negara khatulistiwa seperti Colombia, Indonesia, Zaire, Kongo, Brazil dan Equador mendeklarasikan suatu kesepakatan yang berisi tuntutan terhadap Orbit 
Geostasioner yang letaknya berada diatas wilayahnya. Tuntutan tersebut berdasar kepada aspek wilayah (claim territorial), namun dikarenakan pengaturan terhadap pemanfaatan GSO berdasar pada doktrin first come firs served maka hal tersebut berakibat terhadap adanya ketidakadilan dalam pemanfaatan GSO dimana hanya negara majulah yang mendominasi pemanfaatan GSO dikarenakan tekhnologinya yang unggul dibanding dari negara berkembang.

Sebagai suatu Negara yang berada di bawah garis khatulistiwa terpanjang membuat Indonesia menjadi negara yang memiliki posisi yang panjangnya sama dengan segment GSO yang terdapat di atas wilayah Indonesia. ${ }^{32}$ Melihat letak geografis yang dimiliki oleh Indonesia serta juga melihat manfaat dari GSO yang merupakan fenomena alam yang bisa dijadikan tempat untuk meletakkan satelit-satelit untuk kepentingan Indonesia kedepannya, maka pemanfaatan segment GSO yang terdapat di wilayah bangsa Indonesia harus selalu dapat terjamin guna untuk kelangsungan

32 Ferry Junigwan Murdiansyah. Kajian Hukum Antariksa Modern: Kisah Klasik Untuk Masa Depan

2.

Di http://ferryjunigwan.wordpress.com/2010/01/ 14/kajian-hukum-antariksamodern-kisah-klasikuntuk-masa depan-2/diakses tanggal 10 Oktober 2020. serta keamanan dalam memanfaatkan segmen GSO itu sendiri.33 Indonesia sendiri memiliki kepentingan nasional yang mendasar dan perlu untuk dipertahankan serta diperjuangkan oleh Indonesia, kepentingan tersebut berupa: ${ }^{34}$

1. Adanya perlindungan terhadap bangsa Indonesia terhadap setiap ancaman, tantangan, hambatan serta adanya gangguan yang datang baik dari dalam ataupun dari luar;

2. Menciptakan dan memelihara stabilitas nasional, stabilitas regional serta internasional guna untuk berhasilnya pembangunan nasional selanjutnya;

3. Menjaga ketertiban dunia yang berdasar kepada kemerdekaan, perdamaian abadi dan keadilan sosial.

Adapun cara untuk mewujudkan kepentingan-kepentingan Indonesia tersebut ialah dengan melalui penggunaan GSO yang memanfaatkan kemajuan teknologi serta ilmu pengetahuan dana melakukan pengoptimalan terhadap pemanfaatan GSO agar mendukung pembangunan nasional, guna untuk terwujudnya tujuan

\footnotetext{
33 Ibid

34 Agus Pramono. Dasar-Dasar Hukum Udara dan Ruang Angkasa. Bogor: Ghalia Indonesia, 2000 hal 125
} 
dan cita-cita bangsa Indonesia sebagaimana yang termaktub dalam UUD 1945.

Keputusan Indonesia untuk mempunyai satelit komunikasi sendiri merupakan hal strategis yang dimana masyarakat Indonesia sendiri bisa merasakan manfaatnya, serta juga bisa memberikan pengalaman tersendiri terkait kemampuan teknologi telekomunikasi ruang angkasa oleh Negara Indonesia dan juga teknologi ruang angkasa pada umumnya. Selain memanfaatkan penggunaan GSO melalui satelit-satelit yang telah dioperasikan sendiri, Indonesia sendiri juga sering memanfaatkan satelit negara lain ataupun organisasi internasional guna untuk melakukan navigasi lalu lintas di udara maupun di lautan, juga melakukan pemantuan lingkungan serta pengamatan cuaca. Melihat akan potensi GSO yang sangat bermanfaat hal tersebut tidak menutup kemungkinan bahwa dimasa yang akan datang Negara Indonesia juga akan memanfaatkan GSO dalam keperluan lainnya diluar bidang yang telah dijelaskan diatas. Hal tersebut membuat GSO sendiri merupakan kawasan yang sangat vital bagi Negara Indonesia. ${ }^{35}$
Berdasarkan pernyataan tersebut, terdapat beberapa kepentingan Indonesia terhadap GSO saat ini dan di masa yang akan mendatang ialah: ${ }^{36}$

a. Adanya jaminan yang berkesinambungan untuk penggunaan GSO yang dilakukan oleh Indonesia dalam keperluan penyiaran, meterologi, penyiaran, dan pengembangan bidang-bidang lainnya;

b. Adanya jaminan terhadap satelitsatelit Indonesia agar terhindar dari segala bentuk gangguan serta ancaman dari pihak-pihak lain yang bisa membuat kerugian bagi Indonesia;

c. Adanya jaminan GSO terhadap penggunaan yang bisa memberikan dampak yang negatif terhadap lingkungan dari GSO sendiri maupun bumi, lebih khususnya di wilayah Indonesia;

d. Terdapat peluang bagi Indonesia untuk bisa menggunakan spektrum frekuensi dan slot orbit di GSO pada saat Indonesia membutuhkannya untuk kepentingan nasional;

e. Menghindari segala penggunaan GSO dari bentuk kegiatan yang tidak dimaksudkan untuk perdamaian dan kemanusiaan.

\section{PENUTUP}

GSO merupakan tempat strategis untuk penempatan satelit komunikasi. Pemanfaatan GSO dan pelaksanaannya yang berdasar pada Space Treaty 1967 
serta Konvensi Telekomunikasi

Internasional; subtansi isi rezim khusus usulan negara berkembang, negara khatulistiwa maupun negara lainnya intinya memiliki tuntutan yang relatif sama bahwa pengaturan penggunaan GSO menjadi wewenang UNCOPUOS dan penggunaan GSO dapat diterapkan secara adil dan memperhatikan kepentingan negara-negara khususnya negara yang memiliki karateristik alamiah yang unik dengan GSO, untuk alokasi penggunaan spektrum frekuensi dilakukan secara adil yang berdasar pada ketentuan dalam ITU.

Sebagai suatu Negara yang berada di bawah garis khatulistiwa terpanjang membuat Indonesia menjadi negara yang memiliki posisi yang panjangnya sama dengan segment GSO yang terdapat di atas wilayah Indonesia. Melihat letak geografis yang dimiliki oleh Indonesia serta juga melihat manfaat dari GSO yang merupakan fenomena alam yang bisa dijadikan tempat untuk meletakkan satelit-satelit untuk kepentingan Indonesia kedepannya, maka pemanfaatan segment GSO yang terdapat di wilayah bangsa Indonesia harus selalu dapat terjamin guna untuk kelangsungan serta keamanan dalam memanfaatkan segmen GSO itu sendiri.

\section{REFERENSI}

\section{Buku}

Arifin, Seru, Hukum Perbatasan Darat Antar Negara, Sinar Grafika, Jakarta, 2014.

Agus Pramono. Dasar-Dasar Hukum Udara dan Ruang Angkasa. Bogor: Ghalia Indonesia, 2000.

Boer Mauna, Hukum Internasional

(Pengertian Peranan dan Fungsi

dalam Era Dinamika Global,

Bandung: Alumni, 2005.

E.M. Scoop, Handbook of Geostationary Orbits, USA: Microcosm Inc., Kluwer Academic Publishers, 1994.

H.L. Van Traa-Engelman, Commercial Utilization of Outer Space, Leiden: Martinus Nijhoff Publishers, 1993.

Kaczorowska, A, Public International Law. fourth edition. Routledge. London and New York, 2010.

Sefriani, Hukum Internasional: Suatu pengantar, Rajawali Pers, Yogyakarta, 2009.

\section{Jurnal}

Anjar Supriadhie, Urgensi Keberadaan Hukum Antariksa Dalam Sistem Hukum Indonesia Dan Tantangan Pengembangannya, Jurnal Hukum 
dan Pembangunan Januari - Maret 2001.

Dewi Enggriyeni, Analisis Hukum Perkembangan Pengaturan Geo Stationary Orbit, PROSIDING SIMPOSIUM NASIONAL | BUKITTINGGI 7-8 SEPTEMBER 2017.

Hikmahanto Juwana, Hukum Internasional Sebagai Instrumen Politik: Beberapa Pengalaman Indonesia Sebagai Studi Kasus, ARENA HUKUM Volume 6, Nomor 2, Agustus 2012.

Juajir Sumardi, Hukum Ruang Angkasa (Suatu Pengantar), Jakarta, Pradnya Paramita, 1996.

Lotta Viikari, The Environmental Element in Space Law, Assessing the Present and Charting the Future, Leiden: Martinus Nijhoff Publishers, 2007.

Marina Lits, DKK, International Space Law, BRICS LAW JOURNAL Volume IV (2017) Issue 2.

Michael J. Finch, Limited Space: Allocating the Geostationary Orbit, Northwestern Journal of International Law and Business: Vol.7, Issue 4, 1986.

Muhammad Megah, Kajian Aspek Hukum Internasional Mengenai Kegiatan Wisata Antariksa [Study of International Legal Aspects
Regarding of Space Tourism Activities], Jurnal Analisis dan Informasi Kedirgantaraan Vol. 9 No. 2 Desember 2012.

Silwanus Uli Simamora, Tanggungjawab Negara Peluncur Benda Angkasa Terkait Masalah Sampah Luar Angkasa (Space Debris) Berdasarkan Liability Convention 1972, JOM Fakultas Hukum Volume III Nomor 2, Oktober 2016.

Sri Fatmawati, Analisis Implementasi Pedoman PBB tentang Mitigasi Sampah Antariksa (Analysis on Implementation of UN Space Debris Mitigation Guidelines), Jurnal Analisis dan Informasi Kedirgantaraan Vol. 9 No. 2 Desember 2012.

\section{Internet}

Oxford Research Encyclopedias, 2019, Lihat, https://oxfordre.com/planetarysci ence/view/10.1093/acrefore/9780 190647926.001.0001/acrefore9780190647926-e-75, diakses pada 6 September 2020.

Digital Archive International History Declassified, Pravda Newspaper Article, 'Announcement of the First Satellite', October 05, 1957, Lihat, https://digitalarchive.wilsoncenter. org/document/165454.pdf?v=1b9 
7d7e06318bd134c57860e8ba96a5

d, diakses pada 6 september 2020 .

Lihat,

https://onu-

vienne.delegfrance.org/The-

Committee-in-the-Peaceful-Uses-

of-Outer-Space-COPUOS, diakses 7

September 2020.

United Nations Office For Outer Space Affairs, Treaty on Principles Governing the Activities of States in the Exploration and Use of Outer Space, including the Moon and Other Celestial

Bodies, Lihat,https://www.unoosa.org/oos a/en/ourwork/spacelaw/treaties/i ntroouterspacetreaty.hml, diakses pada 8 September 2020

Michael P. Scharf, Outer Space Law, Lihat, https://www.cambridge.org/core/b ooks/customary-international-lawin-times-of-fundamentalchange/outer-spacelaw/F365CE6892176D25FF589AC4 619FD206, diakses 6 September 2020.

List of Satellites in Geostationary Orbit. http://www.satsig.net/sslist.htm, diakses pada tanggal 10 September 2020.

Ferry Junigwan Murdiansyah. Kajian Hukum Antariksa Modern: Kisah Klasik Untuk Masa Depan 2. Di http://ferryjunigwan.wordpress.co m/2010/01/14/kajian-hukumantariksamodern-kisah-klasikuntuk-masa depan-2/diakses tanggal 10 Oktober 2020. 